\title{
Exploring the linguistic features of Philippine headlines in online newspapers
}

\author{
Regicelle D. Cabaysa \\ regicelle.cabaysa@deped.gov.ph \\ Buenaventura Alandy National High School, Tayabas City 4327, Philippines \\ Calayan Educational Foundation, Inc. Lucena City 4301, Philippines
}

\begin{abstract}
This study is aimed to analyze the linguistic features of Philippine English headlines which are published online by three of the country's national newspapers -INQUIRER.net, philstar.com and mb.com. Using the framework by Mardh (1980) and Mouillaud and Tétu (1989) on the typical features of news headlines in French and English, a sample of 82 headlines were gathered and analyzed from the said online newspapers. The findings revealed that the typical linguistic features of English headlines in the country include the use of present tense for the past tense, the use of to + infinitive for future tense, the use of main verb + infinitive, extensive use of abbreviations, omission of words, the use of colon to introduce direct speech, the use of comma to replace the conjunction "and", and the use of loaded words enclosed in scare quotes.
\end{abstract}

Keywords: Philippine English, headlines, online newspapers

\section{Introduction}

The headline is an essential element of a newspaper. As Crystal (1987, p. 388) defines it, the headline is "one of the most distinctive features of a newspaper. Isani $(2001$, p. 81) considers headline as one of the most creative areas of journalistic writing and, in some aspects, comparable to poetry in that it borrows extensively from linguistic features generally associated with versification" as they are normally written in a sensational way to arouse the readers' interest and curiosity by suing as few words as possible. On the other hand, Reah $(1998$, p. 13) defines it as a "unique type of text as it has a range of functions that specifically dictate its shape, content and structure."

Fries (1987, p. 48) regards headlines as "part of the text but also as texts in their own right." Therefore, headlines can be analyzed as an independent text type which can be divorced from its lead and story. This made headline an interesting topic of most studies.

One of the most prominent contributors on this area is Swales (1990) who studied headline as a genre that acts as mediator between individual and institution in the academic setting. His study, though concentrated on academic communication gave birth to the extension of genre theories through his analysis of genre, speech community and discourse community. His study influenced other researches such as those of Herino and Isani (1994) and Breure (2001) which extend these theories in non-academic and non-professional domains. Van Dijk (1998) attributes certain functions to headlines as cataphoric and informative. His study which focuses on the summarizing role of headline later influenced studies on headline functionality such as those of Dor (2003) and Gattani (2005). For Dor (as cited in Isani 2011, p. 4) headlines are "the negotiators between stories and readers" and have four functions: to summarize, to highlight, to 
attract and to select. Gattani (2005) on the other hand, articulates the broad macro-functions of headline - informative headline, indicative headline, and eye-catcher headline.

Develotee \& Rechniewski (2001) claim that headlines possess linguistic features that expose social, cultural and national representation by giving examples of representations of French in the Australian press and Australians in the French press. Taiwo (2007) classifies headlines into thematic and surface structures and studies the vocabulary and rhetorical devices used in 300 Nigerian newspapers to identify the ideologies behind their construction. Using Critical Discourse Analysis (CDA),Javed and Mahmood (2012) study headlines in Pakistan and conclude that headlines are representations of the editor's ideologies regarding their political inclinations.

Isani (2011 p. 82) affirms the abundance of research on newspaper headlines. However he asserts that there is a "relative dearth of attempts to define the object of the research." As Ingrid Mardh (as cited in Asani, 2011, p. 82) puts forward "No unambiguous definition of headline is known to exist." Despite Asani's (2011) claim, a number of studies on this specific area are considered by the researcher very insightful to her study as they divulge striking linguistic repercussions on the characteristic of the language used in headlines.

Some attempts to establish newspaper headlines as a genre by identifying the features that characterize them was conducted by Allan Bell (1991) who analyzes the 'distinctive telegraphic syntax' of English newspapers. Mardh and Van Dijk (as cited in Asanti, 2011) also amply analyze and describe the distinctive linguistic features used in the linguistic culling of headlines. Ingrid Mardh's (1980) offers framework of the linguistic features of English newspapers which include the omission of articles, the omission of verbs and of auxiliaries, nominalisations, the frequent use of complex noun phrases in subject position, the use of short words, and the use of pun. Mouillaud and Tétu (as cited in Develotte and Rechniewski, 2001) analyze the headlines of Le Monde, a French newspaper and claim that headlines possess features as the suppression of spatial and particularly temporal markers, the use of the present tense of verb as opposed to - or in place of any other tenses, the replacement of verbs by nominalizations and the suppression of declarative verbs."

In the Philippines, Danilo Dayag's book entitled Metadiscourse, argumentation and Asian Englishes: A contrastive rhetoric approach (2009) greatly contributes to the comprehensive study on news stories and headlines published by leading broadsheets in the country. His studies on Philippine English in print media have also extensively covered various linguistic aspects of editorials and news stories.

\section{1 Research Questions}

This research aimed to explore and analyze the linguistic feature of online newspapers in the Philippines from a World Englishes' perspective.

Specifically, this study sought to answer the following questions:

1) What are the linguistic features of Philippine English headlines as exemplified by the three on-line newspapers in the country?

2) What are the salient characteristic of Philippine English headlines?

3) What are the implications of the study in language teaching?

\section{2 Scope and Limitations}

This research was limited only on the careful study of three of the country's leading national newspapers - Philippine Daily Inquirer, Philippine Star and Manila Bulletin (as cited in Dayag, 2008) which have online counterparts. Philippine Daily Inquirer can be accessed as INQUIRER.net; Philippine Star as philstar.com and Manila Bulletin as mb.com. Considering the accepted claims on headline writing, the study analyzed the features of Philippine English headlines in online newspaper based only on the features typical of its type. 


\section{Methodology}

This research used qualitative method. The study relied on Mardh's (1980) typical linguistic features of headlines which include: (1) the omission of articles (2) the omission of verbs and of auxiliaries, (3) nominalisations, (4) the frequent use of complex noun phrases in subject position, (5) the use of short words and (6) the use of pun. The research also anchored on Mouillaud and Tétu's (1989 as cited in Develotte and Rechniewski) framework suggesting that French newspaper headlines have such features as: (1) the suppression of spatial and particularly temporal markers, (2) the use of the present tense of verb as opposed to - or in place of - any other tenses, (3) the replacement of verbs by nominalizations and (4) the suppression of declarative verbs.

The data used in the study were collected from three of the country's leading national newspapers Philippine Daily Inquirer, Philippine Star and Manila Bulletin (as cited in Dayag, 2008) which have online counterparts. These e-newspapers publish minute-by-minute accounts of news stories in the web which can be easily accessed through their sites. The e- newspapers were selected because it is perceived by the researcher as accessible and credible sources of information for the study.

The data were retrieved from the websites of Manila Bulletin (MB), Philippine Star (PS) and Philippine Daily Inquirer (IN) from July 21 - 29, 2016. All 82 headlines were all taken from the National Story segment of each newspaper. Data gathered were tallied, tabulated, analyzed, interpreted using the Framework provided by Mardh (1980) and Mouillaud and Tétu (1989).

The retrieved data were analyzed to look for other salient patterns. The patterns of language features which were found out to have appeared most frequently were listed for analysis. Salient characteristics which were not part of the features provided by Mardh (1980) and Mouillaud and Tétu (1989) were noted.

Findings were collated and a few were presented using tabular form. The explanations of the results were drafted. Further research on related literature was made using books and researches available in the World Wide Web. Related studies which were found out to be relevant were utilized to strengthen the claims made by the researcher based on the generalizations formed from the patterns drawn out.

\section{Results and Discussions}

Because headlines play as precursors to the news, writers construct them in a way that would evoke readers' emotions. Most editors ensure that the choice of expressions in headlines reflects the feelings, opinions and attitudes of people about issues in the news.

Journalistic language as used in headlines is claimed to have characteristics on its own which differentiate it from the 'common core '. Crystal (2003a, p. 85) defines common core as "a range of linguistic features found in all varieties of a language. Halliday (as cited in Abdulla and Salih, 2012) refers to headlines as "little texts" because they have to convey a message through few words. Swan (1995, p.359), considers headlines as the short titles above newspaper reports which sometimes can be "difficult to understand, due to the fact that they are written in a special style."

Considering these accepted claims on headline writing, the study analyzed the features of Philippine English headlines in online newspaper based on the features typical of its type. The sub sections of the research and discussion part present the result and the discussion of the findings.

\subsection{Use of present tense for the past tense}

Swan $(2005$, p. 211) points out that headline producers prefer to use simple tenses rather than 
progressive or perfect forms. It is also important to note that headlines have special language which does not follow the rules of normal English grammar. Table 1 shows the number of headlines which used the three simple tenses of the verb.

Table 1. Verb tense in online newspaper headlines

\begin{tabular}{ll}
\hline Verb tense & Number of Headlines \\
\hline Simple Present & 50 \\
Simple Past & 12 \\
Future & 15 \\
None & 5 \\
\hline
\end{tabular}

The data reveals that from a total of 82 headlines, 51 verbs are in its present tense. The majority of these verbs, however clearly indicates, that an event already occurred and was completed in the past. This means that Philippine headlines adhere to the special tense system of headline writing in English which allows a writer to use the present tense of the verb in reporting past actions.

The following are examples of headlines that used the present tense of the verb to indicate past events.

- Arroyo drives off to freedom in a convoy of vehicles. (IN, July 21)

- Gloria Arroyo walks free from hospital detention (PS, July 21)

- Sara Duterte denies resignation as mayor (MB, July 22)

- Duterte declares ceasefire with communists (MB, July 25)

- Duterte signs FOI order. (PS, July 25)

- Duterte meets with ex-presidents at National Security meeting (IN, July 27)

The findings revealed by the data gathered is supportive of the view of Fowler (1991) and Halliday (1985) that one of the defining characteristics of the register of news headlines is its widespread use of the present tense.

Meanwhile, twelve verbs in the headlines used past tense of the verb to express an action that has taken place in the past. Although the use of present tense in headlines is preferred over the use of past tense, Yoneoka (as cited in Hameed, 2008) states that past tense is occasionally used in headlines to signal that the newspaper has just learned of an event that occurred. The examples below show that past tense can also be used in headlines.

- Quezon Rep. Danilo Suarez elected House Minority Leader (PS, July 27)

- 88 anti -illegal drug cops relieved from duty.

- DOLE ordered to put up one-stop shop for OFWs (IN, July 25)

- JV Ejercito's suspension sought anew in other firearms deal case (IN, July 29)

- Isabela cops, 6 suspects charged for killing of village chief, kin (IN, July 29)

Despite the glaring use of past form of the verb in the previous examples, it is difficult to point out which verbs are in their past tense and which verbs are in their past participle because they have identical forms. For example, the verbs elected, relieved, ordered, sought and charged have the same past and past participle forms.

Reah (1998) considers the language of headlines as compressed and condensed because they aim to give the gist of the news in few languages. This allows headline writers to omit words such as auxiliary verbs. Thus, the omission of auxiliary verbs in the following headlines: 
- Quezon Rep. Danilo Suarez (was)elected House Minority Leader

- 88 anti -illegal drug cops (were) relieved from duty

- Isabela cops, 6 suspects (were) charged for killing of village chief, kin

\section{2 Use of to + infinitive to express future events}

There are no inflected forms for the future in English unlike in other tenses such as the $-\mathrm{d}$ and -ed in the past and $-\mathrm{s}$ and -es in the present tenses. However, a future tense in English can be expressed in varied ways such as:

- Be Going To: am, is, are + going to + base form of the verb

- Shall: Shall + subject + base form of the verb?

- Future Progressive: will be + verb (ing)

- Present Simple and Present Progressive with Future Meaning

The data gathered reveal that in the 15 verbs in the headlines which express the occurrence of future events, nine used the formula to + simple form of the verb, a form which is not usually used in Standard English. The following are some headlines which used the said formula:

- President Duterte: Gov't to attract investments generating high number of jobs. (MB, July 25)

- It's official: $P H$ to host 2017 Miss Universe pageant at MOA(IN, July 25)

- Youth group to ask to strike down 'unconstitutional' curfew ordinances (PS, July 21)

When it comes to writing a headline, Hameed (2008) states that it is common to take the form to + verb instead of 'be going to + verb or will + verb'. This means that, an auxiliary verb and the verb be is omitted when the said form is used. Chin and Tsou, (1997) and Yoneoka, (2002) claim that several publications of newspapers accept the infinitive as a substitute for the future. The reason for permitting the infinitive is to fill in lesser space which may not be possible if other future forms such as will, shall and going to is used. The results show that all three online newspapers allow the use of the formula to + infinitive to express future actions as seen in the examples:

- Sandigan bayan reps en route to hand over Arroyo release papers (MB, July 21)

(Sandiganbayan will hand over Arroyo release papers)

- It's official: $P H$ to host 2017 Miss Universe pageant at MOA(IN, July 25)

(It's official: $P H$ will host/will be hosting 2017 Miss Universe pageant at MOA)

- Coast Guard's first multi-role repose vessel to arrive on August 18 (PS, July 28)

(Coast Guard's first multi-role repose vessel will arrive on August 18)

\subsection{Co-occurrence of main verb forms (finite) and infinitives (non-finite)}

A salient feature of Philippine English newspaper language revealed in the study is the use of main verbs or finite verbs and infinitives or non-finite verbs in a single headline. Tallerman (2015) defines finite verbs as verbs that express tense information. These verbs are commonly called main verbs. On the other hand, non-finite verbs in English are not marked for tense, person/number agreement or any of the other grammatical categories associated with finite verbs. It can be noted from the data that although a verb in the present or past tense is used, Philippine English headline writers commonly used infinitives (to + infinitive) after the main verb. If headlines should be concise, why do headline writers opt to use two verbs, thus making headlines longer? Are headlines in online newspapers provided bigger space compared to headlines printed in broadsheets?

Sixteen of the 62 headlines are found to use the simple present and simple past tense with non-finite verbs in a single headline. The examples of these are shown below.

- President Duterte orders to refrain from addressing him as 'His Excellency' (MB, July 21)

- Duterte pleads to stop war in Mindanao (MB, July 22) 
- $\quad$ Pres, Duterte urges local execs to help solve drug crises. (MB, July 28)

- Binay a sks Comelec to dismiss Pena's poll protest (MB, July 28)

- US offers training, services to help combat terrorism, illegal drugs (MB. July 27)1

- Arroyo drives off to freedom in a convoy of vehicle (IN, July 21)

- Ex-SolGen Mendoza: Plunder law needs to be amended (IN, July 22)

- Duterte asks for emergency power to ease Metro traffic nightmare (IN, July 25)

- DOLE ordered to put up one-stop shop for OFWs (IN, July 25)

- Duterte reiterates vow to raise cops'pay (IN, July 28)

- DILG chief vows to go after cons using his name to dupe LGU execs (IN, July 29)

- Duterte urges MILF, MNLF to cut ties with Abu Sayyaf ( IN, July 26)

- Villanueva seeks to institutionalize Tesda reforms in senate (IN, July 26)

- Cayetano refuses to join any senate floor - for now (PS July 26)

- Duterte pushes for law to make PTV-4 a public service broadcaster (PS, July 26)

- $\quad$ Duterte urged to junk 'lopsided imperialist' EDCA (IN, July 27)

- Duterte advised to exercise restraint on sea row (PS, July 29)

This finding may be used to conduct related studies on the features of Philippine headlines. Previous researches uniformly agreed that headlines need to be concise thus varied forms of making it short are utilized by headline writers. Hameed (2008) states that newspaper headlines use a simplified tense system. He also stresses that it is uncommon to find complex verb forms in headlines. This reason makes this particular finding worthy of further studies.

\subsection{Extensive use of abbreviations}

Abbreviations are commonly used in headlines because of the limited space provided for them and because they require the readers to think of the original word or expression. Ljung (2003, p. 57) defines abbreviations as a "string of letters, most of which are spelled with capital letters." Abbreviations include various ways of shortening words like initialisms, acronymy, clipping and blending. On the other hand, Harley (2006 p. 8) describes abbreviations and acronyms as "behaving like single words but they are actually several words, as far as meaning is concerned."

The use of abbreviations as a means of achieving conciseness is also a typical feature of Philippine English headlines. The table shows the type of abbreviation and number of times each type is utilized in the headlines.

Table 2 Abbreviations in online newspaper headlines

\begin{tabular}{ll}
\hline Type of Abbreviation & Frequency of Occurrence \\
\hline Acronymy & 6 \\
Initialisms & 11 \\
Clipping & 4 \\
Blending & 3 \\
\hline
\end{tabular}

Crystal (2003) defines initialism as the process in which initials are pronounced as separate letters. Denning, Kessler, and Leber (as cited in Lundell 2012, p. 6) point out that initialisms are created because people want to "reduce potentially long names to something manageable." The following headlines contain 
examples of initialisms which proliferate in Philippine online newspapers.

- $\quad$ NBP tunnel exist but sealed off (MB, July 21)

- $\quad$ AFP supports President Duterte's call for unilateral ceasefire (MB, July 21)

- $\quad \underline{\text { SC }}$ majority: Sandiganbayan abused discretion in GMA case. (PS, July21)

- $\quad$ NBI: Peter Lim willing to submit investigation (IN, July 21)

- DOLE ordered to put up one-stop shop for OFWs (IN, July 22)

- Duterte signs FOI order( PS, July 25)

- $\quad$ Supreme Court issues TRO on curfew. (MB, July 26)

- Duterte urges MILF, MNLF to cut ties with Abu Sayyaf. (IN, July 26)

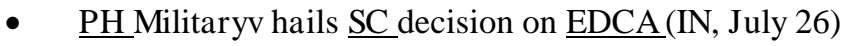

- $\quad$ Government panel confronts NDFP over Davao ambush (PS, July 29)

Marchand (1969) states that word formations are mostly used to create names of organizations. Bauer (1988, p. 39) defines acronyms as "words formed from the initial letters in a name, title or phrase." He also clarifies that acronyms should be distinguished from abbreviations because acronyms are pronounced as new words, and not just a sequence of letters.

The following acronyms used in headlines are exemplified in the following examples:

- $\quad$ Foreign policy experts call for ASEAN 'coalition' over South China Sea dispute (MB, July 21)

- DOLE ordered to put up one-stop shop for OFWs_(IN, July 22)

- Brillante Mendoza explains SONAcamera-world. (M.B., July 26)

- PH Militarv hails SC decision on EDCA(IN, July 26)

The data also found out that some words in the online headlines are shortened through clipping. Clipping is a word formation process in which a word is reduced or shortened without changing the meaning of the word. Crystal (as cited in Abdulia and Salih, 2012) believes that clippings are typical in headlines where a part of a word stands for the whole. Saxena (2006), states that the use of shortened words allows writers to provide more information in a headline. The following are clipped words found in the data.

- President Duterte: Gov't to attract investments generating high number of jobs (MB, July 25)

- Quezon Rep. Danilo Suarez elected House Minority Leader (PS, July 27)

- DILG chief vows to go after cons using his name to dupe_LGU execs (IN, July 29)

- Rehab of drug users will be prioritized - President Duterte (MB, July 25)

Lehrer (2007, p. 117) defines blends as "underlying compounds which are composed of one word and part of another, or parts of two or three other words." Richardson (as cited in Abduliah and Salih, 2012) states that words can also be formed by blending which entails using the first part of a word with the last part of another. Lehrer (2007, p. 115) claims that blends "occur mostly in media, advertisements, and product names, functioning to gain attention." In the data gathered several headlines appeared to have used blending to maximize space and arrest the reader's attention. Crystal (as cited in Abduliah and Salih, p. 197 ) believes that blending are "eye-catching and exciting." The examples show how blending is used in Philippine headlines.

- Ex-SolGen MenDoza: Plunder Law needs to be amended (IN, July 22)

- Con-con a priority in $17^{\text {th }}$ Congress, says Alvarez (PS, July 22)

- Palace: no self-serving intentions in pushing for Con-ass (IN, July 29)

It is also interesting to note that several headlines use more than one abbreviated forms as substitute for complete words in a single headline as shown below.

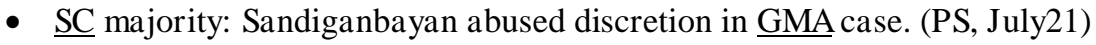

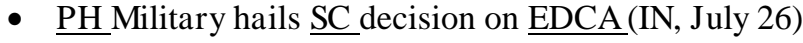

- $\quad$ PNP suspends police ops vs communists (PS, July 27)

Abdulia and Salih (2012) state that abbreviations in general, are widely used in headlines because they 
save space on page and they also require the readers to stop a little to think of the original word or expression. On the other hand, Saxena (2006), points out that the use of abbreviation may sometimes obscure meaning so writer should learn how to use them sparingly.

\section{5 Omission of words}

Because a limited space is provided for headlines, they need to be short but concise. Moreover, since headlines address reader's needs, long and complex headlines need to be avoided to save the reader's time and patience. The reason for using as few short words as possible is constraint space provided for headlines in newspapers. Praskova (2009) attribute to Straumann the use of the term block language. According to Mardh, (1980) block language occurs most frequently occurs in book-titles, diaries, advertisements, dictionaries, catalogues, labels and headlines. One of the characteristics of block language, according to Praskova (2009) is the omission of words such as articles and auxiliary verbs. Clark (2007) notes that content words such as nouns, main verbs and adjectives, which are necessary to express meaning, are not eliminated in headlines. Majeed (2012) believes that closed class, grammatical function word items in headlines are omitted since they have low information value. These include auxiliaries, articles and words that can be understood from the context. Tallerman (2011, p. 54) categorizes articles, demonstratives, wh- determiners, quantifiers, possessive determiners and pronouns as members of "overarching category - determiner." The reasoning behind this, according to Tallerman (2011) is that only one item from these selections can be put in a single slot before a noun.

Table 4 Number of omitted words in PE headlines

\begin{tabular}{ll}
\hline Type of Omitted Words & Number \\
\hline Demonstrative articles & 45 \\
Auxiliary verbs & 15 \\
Conjunctions & 9 \\
\hline
\end{tabular}

The data reveals that in the 45 headlines, a demonstrative is omitted. The huge chunks of the words omitted are definite and indefinite articles.

- Gloria arroyo walks free from (the) hospital detention (PS, July 21)

- Dissenting opinions of (the) SC justices on Arroyo case (PS, July 21)

- Alunan could be (the) special envoy to China if FVR turns down Duterte offer (PS, July 21)

- Alunan could be (the) special envoy to China if FVR turns down Duterte offer (PS, July 21)

- (The) rehab of drug users will be prioritized - President Duterte (MB, July 25)

- Duterte declares ceasefire with (the) communists (MB, July 25)

- Erap sets P100k for (the) arrest of Quiapo road rage suspect (PS, July)

- Researches zero in on few proteins as (a) cancer drug test (MB, July 29)

In addition, the corpus gathered show that only two of the 84 headlines are found to have used determiners as shown in the examples below:

- Arroyo drives off to freedom in a convoy of vehicle (IN, July 21)

- Con-con $\underline{\text { a }}$ priority in $17^{\text {th }}$ Congress, says Alvarez (PS, July 21)

The majority of headlines also illustrate removed auxiliary verbs. Auxiliaries, according to Halliday (1985) are usually left out and the verb be is considered the most omitted auxiliary. The omission, according to Bedrichova (as cited in Abdulia and Salih 2008) does not affect the decoding of the message and readers can still easily recover the original structure as exemplified by the headlines below.

- 30,000 protesters (were) in 'historic', 'peaceful' SONA rally (IN, July 25) 
- Philippine's oil (is) still in troubled waters after South China Sea ruling (MB, 'July 25)

- Bulacan cop (was) charged after confessing ties to drugs (IN, July 22)

- Kerry: US (is) avoiding 'confrontation' in sea row (MB, July 27)

- 88 anti-illegal drug cops in QC (were) relieved from duty (IN, July 27)

- Palace: (There is) No self-serving intentions in pushing for Con-ass (MB, July 29)

Praskova (2009) also points out that a typical feature of block language is a heavily modified noun phrase. Bedrichova (as cited in Abdulia and Salih, 2012) claims that the use of modified noun phrases allows the headline writer to delete the participants and the indication of time. This assertion is exemplified in the headlines found in the data gathered. The examples are noun phrases which are heavily modified.

- Dissenting opinions of SC justices on Arroyo's case (PS, July 21)

- 30, 000 protesters in 'historic, 'peaceful' SONA rally (IN, July 25)

- Palace: No self-serving intentions in pushing for Con-ass (IN, July 29)

3.6 Use of colon to introduce direct speech

A colon is typically used to introduce lists or texts, give emphasis to a word, clarify composition titles and present dialogue. Quirk et. al. (as cited in Patt, 2013, p. 106) describe the function of colon in terms of "decreasing closeness - that is, the interdependence between two punctuation units is perceived lesser if separated by a colon." Saxena (2006 p. 189) clarifies that colon in headlines are used to "replace the attributive verb as it saves space." The examples show how colon is used as substitute for assertive verb and to introduce a direct speech without quotation marks.

- Duterte: Federalism will bring peace in Mindanao (MB, July 22)

- Duterte to troops: Be not afraid to kill drug traders, criminals (In, July 21)

- NBI: Peter Lim willing to submit to investigation (IN, July 21)

- Ex- Solgen Mendoza: Plunder law needs to be amended (IN, July 22)

- Alvarez: No minors to be punished with death penalty (IN, July 22)

- SC majority: Sandiganbayan abused discretion in GMA case (PS, July 21)

- Estelito Mendoza: GMA can file case for unlawful detention (MB, July 22)

- Duterte: Corporate taxes to be lowered (PS, July 25)

- Analyst: SONA shows Duterte's 'moderate' stance on West Philippine Sea dispute (PS, July 27)

Colons are not merely used to introduce direct speech. In the examples shown, colons are also used to emphasize an information.

- Duterte's SONA: Music to businessmen's ears (MB, July 26)

- LOOK: Former presidents gather for National Security Council Meeting (MB, July 27)

- Spotted: 'Bahag' at SONA highlights pride in cultural identity. (PS, July 28)

- It's official: PH to host 2017 Miss Universe pageant at MOA (IN, July 28)

- SAF takeover: P1.1-M contraband seized at Bilibis (PS, July 29)

3.7 Use of comma to replace the conjunction 'and'

Quirk (1985) believes that the comma is the most flexible mark in the range of its use. Saxena (2006) claims that comma play a special role in headlines since this mark is used to take the place of the conjunction and while at the save time saving space. In formal writing however, the semicolon occurs frequently and is most closely related to the conjunction often substituting it in cases of asyndetic coordination. The data used as examples show how a comma in headlines replaces the conjunction and.

- Duterte to troops: Be not afraid to kill drug traders, criminals (IN, July 21)

- Duterte asks for soldiers' sacrifice in fight vs terrorism, drugs (IN, July 21) 
- Duterte: Corporate, personal taxes to be lowered (PS, July 25)

- US offers training, services to help combat terrorism, illegal drugs (MB, July 27)

- ' Carina' to bring rains over Bicol, Eastern Samar (PS, July 29)

- Isabela cops, 6 suspects charged for killing of village chief, kin (IN, July 29)

\section{8 Use of loaded words in scare quotes}

Ludwig (as cited in Paraskova, 2009) cites that the best headlines both 'tell and sell', that is, they tell the reader quickly what the news is and persuade the reader that the story is worth reading." The choice of lexical words in headline thus creates an impression to its reader and produces its desired effect on them.

Because headline writers favor words that are shorter and dramatic, newspaper headlines tend to use a lot of distinctive vocabulary. They usually choose the most emphatic and effective words to create strong headlines. Swan (2005) states that headline vocabulary is characterized as being unusual and sensational. Bucaria (as cited in Abdulia and Salih 2008) points out that one of the most important features of headlines is the use of 'loaded' words and expressions which carry strong connotation and attract attention.

Reah (1998) views that loaded words are words or phrases which have strong emotional implications that may elicit positive or negative attitudes towards the hidden meaning of the words used.

In the data gathered, it can be claimed that Filipino headline contributors utilize loaded words for the same reasons stated above. However, it can be noticed that these loaded words are placed in single quotation marks making it really stand out in the headline. By using single quotation marks which are usually preferred by headline writers to save space, the words enclosed appeared as a word meant for different interpretations. Quotation marks in the following headlines can also mean "so called." They are used by headline contributors to stress or emphasize an idea since only individual words are enclosed in quotation marks. This style makes the words inside the quotation disputable or questionable. Abdulia and Salih (2012) conclude that the ambiguity these words create help in achieving the attention- seeking role of headlines. With this, readers continue reading the story to find out the truth and resolve the ambiguity. Below are the examples of Philippine headlines with obviously loaded words enclosed in single parenthesis.

- Analyst: SONA shows Duterte's 'moderate' stance on West Philippine Sea dispute (PS, July 27)

- $\quad$ Duterte urged to junk 'lopsided imperialist' EDCA (IN, July 27)

- 30, 000 protesters in 'historic,' 'peaceful' Sona rally (IN, July 25)

- DOJ chief: PH won't try to 'inflame' China on maritime roe (IN, July 28)

- US troops to have 'persistent, intermittent' presence in Philippines (PS, July 28)

It can also be claimed that Philippine headline writers use scare quotes. Scare quotes are quotation marks placed around a word or a group of words. According to Trask, (1997) scare quotes are used by writers who wish to distance themselves from a word which they consider odd or strange, colloquial from the standard writing, inaccurate or misleading. He adds that scare quotes are often used to express irony, derision, sarcasm or skepticism. In example a, the word moderate is used carefully by the headline writer for several reasons - to arrest reader's attention, to distance himself from a possible misleading contention on the said dispute and to affect the readers to feel positively or negatively about the "not so vehement" stance of the Philippine president on the controversial issue. The examples show may also be considered an indication of Philippine headline writers' cautious manner of expressing "objectively" the facts of the events. 


\section{Conclusions}

- The study of the corpus shows that the language and grammar used in headline writing often deviates from the usual norms and standards of English language. Therefore, it can be assumed that the language of headline, similar to the language of literary texts, is indeed distinct in its own type.

- The linguistic qualities of Philippine English headlines which are published online are characterized by certain features as revealed by the corpus. These linguistic features include:

1. the use of present tense for the past tense

2. the use of to+ infinitive to express future tense

3. the use of main verb + infinitive

4. extensive use of abbreviations

5. omission of words

6. the use of colon to introduce direct speech

7. the use of comma to replace the conjunction "and"

8. the use of loaded words in scare quotes

- The results of the analysis show that the majority of headlines published online were purposively written to adjust to space constraints. Varied forms of shortening the headlines such as the use of abbreviations, omission of words specifically closed class and grammatically function words, substitution of the conjunction "and" by a comma, and the use of colon for say/s or said are extensively used by Filipino writers to address the space limitation for online newspapers. These features are also found in the framework outlined by Mardh (1980).

- The use of initialisms, acronyms, blending and clipping was widely utilized as a means of producing shorter headlines. These shortening forms are clear manifestations of the headline writers' adherence to the use of block language, a language variety which is common not only in headlines but also in advertisements, slogans and signages.

- It can also be concluded that the use of block language in Philippine headlines do not interfere the understanding of its intended meaning because omitted words can be recovered easily from the context.

- Other linguistic features of Philippine online headlines such as the use of present tense for the past tense and the use of to + infinitive for the future tense are considered acceptable tenses in headline writing. This feature is apparent in most headlines in the corpus except for the cited four headlines without verbs. The use of the present simple in headlines is considered a canonical tense in headline writing and can be interpreted in connection with its feature - suppression of temporal markers as outline by Mouillaud and Tétu (1989).

- A distinguishing feature of Philippine headlines is the co-occurrence of both finite and non-finite verbs. A shorter word or expression may be utilized by writers to substitute longer verbs to make the headlines shorter and to save space. The use of longer verbs is unexpected from a text type which usually requires fewer words, thus, this feature calls for further studies.

- Another salient linguistic feature worthy of consideration as future research topic is the use of loaded words. The potential of getting the readers' interest and varying interpretations of the meaning is intensified by the use of scare quotes which makes it highly identifiable as it stands out in the group. It is interesting to note that these loaded words are connected with highly controversial events in the country; therefore the act of enclosing them in scare quotes must have been done intentionally by headline writers to distance themselves from a possible involvement on the issues they raised. 
- It can be concluded that the features of English headlines in the Philippines create a unique and distinctive use of language in its genre, meaning newspaper headlines are written in a special kind of language with its own grammar rules.

\section{Implications}

With the features revealed in the study, headlines may be considered a good springboard for Filipino teachers who wish to enhance student's creativity on the qualities of effective language use such as conciseness, correctness, completeness and concreteness of the message. Moreover, headlines are considered authentic materials which can provide students additional leaning on how English language can be used creatively. Exercises aimed at honing students' versatility on the use of English language can be done by writing or assigning headlines to their stories. However, headlines cannot be used to teach Standard English grammar as its language is considered a deviation from the norms.

\section{References}

Abdulla, Majeed Abdul and Younis Mehdi Salih. (2012) Linguistic Features of Newspaper Headlines. In Journal of Al_Anbar University for Language and Literature Issue: 7- Year. Retrieved from http://www.iasj.net/iasj?func=fulltext\&aId=64644

Bell, Allan. (1991). Language of News Media. John Wiley and Sons.

Clark, Caroline M. de B. (2007). Views in News Textbook. LED Edizioni

Universitarie. [Online]. Retrieved from the Internet 19 August2016:http://www.lededizioni.com/lededizioniallegati/clarckviews.pdf

Crystal, D. (2003). The Cambridge Encyclopedia of the English Language. UK:

Cambridge University Press. Retrieved from http://culturaldiplomacy.org/academy/pdf/research/books/nation_branding/ English_As_A_Global_Language_-_David_Crystal.pdf

Chin, Andy Chi-on, and Benjamin K.Y. Tsou (1997). Subject Ellipsis in Chinese News Headlines: Hong Kong: University of Hong Kong Press.

Develotte and Rechniewski. ( 2001) Discourse analysis of newspaper headlines: a methodological framework for research into national representations. Retrieved from http://wjfms.ncl.ac.uk/titles.htm.

Dor, Daniel. (2003). On Newspaper Headlines as Relevance Optimizers . In Journal of Pragmatics. (pp. 721 - 735).

Fowler, R. (1991). Language in the News. Discourse and Ideology in the Press. Routledge: London and New York

Halliday, M.A.K. (1967) Grammar, Society and the Noun. London

Halliday, M. A. K. (1985). An Introduction to Functional Grammar. London: Edward Arnold.

Hameed, Tahseen. (2008). Tense in News Headlines. Diala, Jour Volume 30, p. 264 Diyala University/College of Education. Retrieved from http://www.iasj.net/iasj?func=fulltext\&aId=17758

Harley, H. (2006). English Words: A Linguistic Introduction. Malden, MA: Blackwell Publishing.

Isani, Shaeda. (2011) Of headlines \& headlinese: Towards distinctive linguistic and pragmatic genericity. Asp., 60. DOI : 10.4000/asp. 2523

Kirkpatrick, Andy. (2006). A Lingua Franca Approach? Implications for research and training. In Hashim, A and Hassam N. (Eds.) Prospects, Perspectives and Possibilities (pp. 9-20). Malaysia: Malaya Press.

Ljung, M. (2003). Making Words in English. Lund: Studentlitteratur.

Lundell, Ida. (2012). 'LOL', 'OMG' and Other Acronyms and Abbreviations A study in the creation of initialisms. Retrieved from www.diva-portal.se/smash/get/diva2:601211/FULLTEXT01.pdf

Mahmood, Asim Muhammad, et. al. (2011). A Critical Discourse Analysis of the Headlines of Budget of Pakistan FY2011-2012. In Interdisciplinary Journal of Contemporary Research in Business. Vol 3. No. 5. (pp. 120-131)

McArthur, T. (1992). The Oxford Companion to the English Language. Oxford and New York: Oxford University Press.

Marchand, H. (1969). The Categories and Types of Present-Day English Word-Formation.

Mardh , I. (1980) Headlinese: On the Grammar of English Front Page Headlines. Malmo. 
Metcalf, Allan. (2013). The Grammar of (Newspaper) Headlines. In The Chronicle of Grammar Education. Retrieved from http://chronicle.com/blogs/linguafranca/2013/02/18/the-grammar-of-newspaper-headlines/

Munat, Judith. (2007). Lexical Creativity, Texts and Contexts. Amsterdam: John Benjamins Publishing. Company. Retrieved from www. skase.sk/Volumes/JTL11/pdf_doc/6.pdf.

Patt, Sebastian. (2010). Punctuation as means of medium dependent presentation structure in English. Retrieved from https://www.iaak.uni-bonn.de/people/esser/punctuation

Prásková, E. (2009). Grammar in Newspaper Headlines. Retrieved from dspace.upce.cz/bitstream/10195/34683/1/PraskovaE_GrammarIn_PH_2009.pdf

Saxena, Sunil. (2006). Headline Writing. New Delhi. Sage Publications. Retrieved from https://books.google.com.ph/books/about/Headline_Writing.html?id=7MqGahiFQScC\&redir_esc=y.

Quirk, R., et al. (1991). A Comprehensive Grammar of the English Language.Longman Group Ltd.

Quirk, R., S. Greenbaum, G. Leech, J. Svartvik (1985) A Comprehensive Grammar of the English Language. London and New York: Longman.

ReahD. (1998). The Language of Newspapers. London and New York: Routledge.

Swan, M. (1995). Practical English Usage. Oxford: Oxford University Press.

Swales, Feak (2004): Academic Writing for Graduate Students, University of MichiganPress.

Taiwo, Rotimi. (2007). Language, Ideology and Power Relations in Nigerian Newspaper Headlines. In Nebula 4.1. Retrieved from http://www.nobleworld.biz/images/ Taiwo2.pdf.

Talleman, Magie. Understanding Syntax, Third Edition. UK: Hodder Education.

Thomas, Susan. (1993). Review of Allan Bell 'The language of news media' Language in Society, 22, pp 115-121. doi:10.1017/S004740450001695X.

Trask, L. (1997). Scare Quotes. Retrieved from http://www.sussex.ac.uk/informatics/punctuation/quotes/scare

Van Dijk, T.A.(1986). News Schemata. In CR Cooper \& S Greenbaum (Eds).Studying Writing :Linguistic Approaches. London: SAGE.155-185.

Van Dijk, T. A. (1988). How 'They' hit the headlines. Ethnic minorities in the press. In G. Smitherman-Donaldson \& T. A. van Dijk (Eds.), Discourse and Discrimination. (pp. 221- 262). Detroit, MI: Wayne State University Press.

Van Dijk, T. A. (1988). News analysis: Case studies of international and national news in the press. Hillsdale, N.J.: L. Erlbaum.

Van Dijk, T. A. (1988). News as discourse. Hillsdale, NJ: Lawrence Erlbaum Associates.

Van Dijk, T. A. (1989). Critical News Analysis. Critical Studies, 1(1), 103-126.

Van Dijk, T. A. (1991). Racism and the press. London New York: Routledge.

Van Dijk, T. A. (1991). The interdisciplinary study of news in the press. In K. BruhnJensen \& N. Jankowksi (Eds.), In Handbook of Qualitative Methods in Mass Communication Research. (pp. 108-120). London: Routledge.

Wright, Kate. (2012). Reality Without Scare Quotes, Developing the case for critical realism in journalism research. Journalism Studies, Vol. 12, No. 2. DOI: 10.1080/1461670X.2010.50956.

Yoneoka, Judy. (2000).Newspaper English .n.p. :n.p 